Agata NodŻAK ${ }^{1}$

\title{
Sprawozdanie z seminarium naukowego Jean Monnet Module z dnia 26 marca 2021 r. pt. „Pytania prejudycjalne jako środek ochrony praw podstawowych"
}

W dniu 26 marca 2021 r. odbyło się seminarium naukowe pt. „Pytania prejudycjalne jako środek ochrony praw podstawowych" (dalej: seminarium JMM), zorganizowane w Instytucie Prawa i Ekonomii Uniwersytetu Pedagogicznego im. Komisji Edukacji Narodowej w Krakowie. Seminarium JMM stanowiło jedno z pierwszych przedsięwzięć naukowych, zaplanowanych i zrealizowanych w ramach projektu „Protection of Fundamental Rights in UE” (nr projektu 620847-EPP-1-2020-1-PL-EPPJMO-MODULE), finansowanego z Programu Erasmus+, Jean Monnet. Celem tego spotkania naukowego było porównanie wyników badań (do roku 2021) z praktycznymi doświadczeniami Naczelnego Sądu Administracyjnego (NSA) i jego orzecznictwem. Niniejsze przedsięwzięcie naukowe zostało zaadresowane przede wszystkim do naukowców oraz sędziów NSA, zajmujących się problematyką procedury pytań prejudycjalnych, o której mowa w art. 267 Traktatu o funkcjonowaniu Unii Europejskiej (TFUE), jako zinstytucjonalizowanego mechanizmu dialogu między Trybunałem Sprawiedliwości Unii Europejskiej (TSUE) a sądami krajowymi, w szczególności sądami administracyjnymi. Organizacja seminarium JMM zakładała również udział przedstawicieli administracji sądowej oraz środowiska studenckiego.

Otwarcia seminarium JMM dokonali przedstawiciele władz Uczelni w osobie Prorektora ds. Nauki, Pana prof. dr hab. Michała Rogoża, oraz Dyrekcji Instytutu Prawa i Ekonomii w osobie Pani prof. dr hab. Kazimiery Juszki, jak również ówczesnej Module Leader projektu, Pani prof. dr hab. Anny Kalisz. W ramach programu seminarium JMM przewidziane zostało omówienie takich cząstkowych zagadnień, jak: korzystanie z pytania prejudycjalnego w polskich sądach administracyjnych - procedura; rola sądów administracyjnych $\mathrm{w}$ ochronie praw podstawowych; prawa podstawowe

1 Dr Agata Nodżak, Instytut Prawa i Ekonomii, Uniwersytet Pedagogiczny im. Komisji Edukacji Narodowej w Krakowie; kierownik projektu pn. „Protection of Fundamental Rights in UE” (nr projektu 620847-EPP-1-2020-1-PL-EPPJMO-MODULE), Program Erasmus +, Jean Monnet. 
UE w orzecznictwie sądów administracyjnych - wybrane sprawy, przykłady z praktyki orzeczniczej; TSUE - Europejski Trybunał Praw Człowieka (ETPC) - Naczelny Sąd Administracyjny w Polsce - czy istnieje praktyczny dialog sądowy? Powyższe zagadnienia zostały omówione w ramach dwóch paneli:

1) Panel I - „Korzystanie z pytania prejudycjalnego w polskich sądach administracyjnych czy istnieje praktyczny dialog sądowy?” (moderatorzy: dr Agata Nodżak, dr Monika Skowrońska);

2) Panel II - „Prawa podstawowe UE w orzecznictwie sądów administracyjnych - wybrane sprawy, przykłady z praktyki orzeczniczej" (moderator: dr Piotr Uhma).

Pierwszy panel rozpoczął prof. dr hab. Stanisław Biernat z Katedry Prawa Europejskiego, Uniwersytetu Jagiellońskiego w Krakowie, który wygłosił referat pt. „Czego uczą pytania prejudycjalne sądów administracyjnych”. Przedmiotem wystąpienia były rozważania dotyczące zagadnienia pytań prejudycjalnych w działalności krajowego sądownictwa, w szczególności polskich sądów administracyjnych. W swoim wystąpieniu prelegent odniósł się do kilku wybranych przykładów odesłań prejudycjalnych sądów administracyjnych i wyroków TSUE wydanych w odpowiedzi na przedłożone pytania, po to by przedstawić nie tyle ilość, co obraz tematyki pytań prejudycjalnych kierowanych przez sądy administracyjne, a w wyniku przeprowadzonej analizy zaprezentować zagadnienia bądź rozstrzygnięcia, istotne zarówno z perspektywy prawa unijnego, jak i prawa krajowego.

Następnie głos zabrał prof. dr hab. Maciej Szpunar z Uniwersytetu Śląskiego w Katowicach, pełniący obecnie również funkcję Rzecznika Generalnego TSUE. Mając na uwadze tę funkcję i związane z jej pełnieniem doświadczenia, prelegent podzielił się swoimi spostrzeżeniami na temat praktycznych aspektów związanych ze stosowaniem instytucji pytań prejudycjalnych, wygłaszając referat pt. „Pytania prejudycjalne z perspektywy TSUE".

Kolejny referat pt. „Uwagi na temat skutków i wykonywania orzeczeń prejudycjalnych", został zaprezentowany przez prof. dr hab. Ninę Półtorak z Katedry Prawa Europejskiego na Uniwersytecie Jagiellońskim w Krakowie. Jako sędzia WSA w Krakowie oraz sędzia Sądu UE (będącego częścią Trybunału Sprawiedliwości Unii Europejskiej), Pani Profesor w ramach swojego wystąpienia mogła podzielić się swoimi rozważaniami na temat charakteru i zakresu oddziaływania orzeczeń TSUE zapadłych na skutek wystąpienia z pytaniami prejudycjalnymi, oraz problemów związanych $\mathrm{z}$ ich wykonywaniem na gruncie krajowym.

W trakcie pierwszego panelu wygłoszony został również referat pt. „Procedura prejudycjalna jako forma współpracy sądowej: NSA TSUE - ETPC", przez prof. dr hab. Annę Kalisz (Instytut Prawa i Ekonomii, Uniwersytet Pedagogiczny im. Komisji Edukacji Narodowej w Krakowie) oraz dr Annę Chmielarz-Grochal (Uniwersytet Łódzki). Co znamienne, 
obie prelegentki reprezentując również NSA w Warszawie (Wydział Prawa Europejskiego), mogły przedstawić praktyczne aspekty związane ze stosowaniem instytucji pytań prejudycjalnych, przebiegiem procedury występowania przez polskie sądy administracyjne z pytaniami prejudycjalnymi. Interesujące okazało się przedstawienie wniosków dotyczących istoty pytań prejudycjalnych jako instrumentu dialogu sądowego na linii NSA TSUE - ETPC, przede wszystkim w sferze ochrony praw podstawowych.

Ostatnim wystąpieniem w I panelu był referat pt. „Wykonywanie orzeczeń TSUE przez sądy administracyjne - obowiązki traktatowe a rzeczywistość prejudycjalna", wygłoszony przez prof. dr hab. Joannę Wegner z Uniwersytetu Łódzkiego. W wystąpieniu zostały zaprezentowane - z perspektywy procesualisty - interesujące wątki związane $\mathrm{z}$ wykonywaniem orzeczeń TSUE przez sądy krajowe.

Zwieńczeniem wystąpień $w$ ramach I panelu była interesująca dyskusja, połączona $\mathrm{z}$ zadawaniem pytań poszczególnym prelegentom. W dyskusji oprócz panelistów głos zabrali: prof. dr hab. Jacek Chlebny, dr Bogumił Naleziński, czy Przemysław Florjanowicz-Błachut.

Drugi panel zatytułowany „Prawa podstawowe UE w orzecznictwie sądów administracyjnych - wybrane sprawy, przykłady z praktyki orzeczniczej" otworzyło wystąpienie prof. dr. hab. Grzegorza Krawca (Instytut Prawa i Ekonomii, Uniwersytet Pedagogiczny im. Komisji Edukacji Narodowej w Krakowie. Prof. Grzegorz Krawiec, reprezentując również Biuro Pełnomocnika Terenowego Rzecznika Praw Obywatelskich w Katowicach, wygłosił referat pt. „Rzecznik Praw Obywatelskich a sądownictwo administracyjne - wzajemne relacje (perspektywa praktyczna)", w którym przedstawił interesujące rozważania na temat wzajemnego oddziaływania tych organów i instytucji na przykładzie spraw z zakresu rejestracji stanu cywilnego dzieci par jednopłciowych.

Problematyka współczesnego sądownictwa była kontynuowana w ramach kolejnego referatu, zaprezentowanego przez dr Agnieszkę Kastelik-Smazę w referacie pt. „Procedura prejudycjalna w kontekście prawa do sądu". Głównym zagadnieniem, będącym przedmiotem rozważań, było poszukiwanie odpowiedzi na pytanie, czy odmowa wystąpienia z pytaniem prejudycjalnym przez sąd ostatniej instancji może być rozumiana jako naruszenie prawa jednostki do sądu. Zagadnienie to zostało zaprezentowane w odniesieniu do poglądów doktryny oraz przykładów z praktyki orzeczniczej sądów niemieckich, austriackich oraz działalności orzeczniczej TSUE.

Następnie głos zabrała dr Alicja Sikora-Kaleda (Uniwersytet Jagielloński, UCLouvain, Université Saint Louis, Bruksela, CEDRE (Centre d'étude du droit de l'environnement); Rada Unii Europejskiej i Rada Europejska, Służba Prawna) w ramach wystąpienia pt. „Ochrona praw jednostek i środowiska naturalnego $\mathrm{w}$ ramach procedury $\mathrm{z}$ art. 267 TFUE”. $\mathrm{W}$ referacie poruszone zostały zagadnienia dotyczące roli sądów administracyjnych w zakresie ochrony środowiska oraz znaczenia procedury pytań 
prejudycjalnych dla ochrony prawnej jednostek, czy też szerzej ujmując dla egzekwowania unijnych norm ochrony środowiska.

Przedostatnim wystąpieniem w ramach II panelu było zaprezentowanie przez mgr. Grzegorza Karwatowicza (WW Grynhoff i Partnerzy Radcowie Prawni i Doradcy Podatkowi Sp. p.) referatu pt. „Wykładnia definicji legalnej nieprawidłowości w świetle wyroku TSUE C-406/14 (pytanie prejudycjalne WSA w Warszawie)". W wystąpieniu zostały przedstawione rozważania na temat znaczenia i roli instytucji pytań prejudycjalnych w stosowaniu prawa przez sądy krajowe, a w szczególności w przypadkach występowania wątpliwości, co do wykładni definicji legalnych pojęć prawnych (na przykładzie definicji legalnej pojęcia „nieprawidłowości”).

Jako ostatni w trakcie seminarium JMM został zaprezentowany referat pt. „Ochrona praw dziecka z perspektywy praw podstawowych UE”, przez dr Annę Juryk z Uniwersytetu Ekonomicznego w Krakowie. Swoje rozważania prelegentka prowadziła w odniesieniu do postanowień Karty Praw Podstawowych, traktujących o ochronie praw dziecka oraz odnosząc to zagadnienie do praktyki orzeczniczej sądów administracyjnych, dotyczącej m.in. odmowy transkrypcji zagranicznych aktów stanu cywilnego dzieci par jednopłciowych.

Podsumowaniem wystąpień w ramach II panelu była również interesująca dyskusja, połączona z zadawaniem pytań poszczególnym prelegentom. W dyskusji oprócz panelistów z II części seminarium głos zabrali: prof. dr hab. Stanisław Biernat, prof. dr hab. Sylwia Majkowska-Szulc, czy dr Monika Skowrońska.

Zamknięcia seminarium JMM dokonała dr Agata Nodżak, dziękując prelegentom i gościom za zainteresowanie i udział w tym wydarzeniu naukowym oraz zapraszając do uczestnictwa w kolejnych przedsięwzięciach zaplanowanych w ramach realizacji projektu Jean Monnet Module.

Seminarium JMM stanowiło znakomitą okazję do wymiany poglądów $\mathrm{w}$ odniesieniu do wielu interesujących problemów związanych z instytucją pytań prejudycjalnych, przebiegiem procedury jej stosowania i jej skuteczności oraz znaczenia w kontekście ochrony praw podstawowych. Z wypowiedzi uczestników seminarium JMM można było wynieść wnioski dotyczące realnej wartości tej instytucji, w szczególności w obecnej sytuacji występowania w poszczególnych państwach europejskich różnego rodzaju kryzysów - ekonomicznych, humanitarnych, prawnych czy zdrowotnych skutkujących ustawicznymi naruszeniami podstawowych praw człowieka, praw jednostki.

Wprowadzony w połowie marca $2020 \mathrm{r}$. stan zagrożenia epidemicznego w kraju oraz wynikające $z$ niego decyzje władz uczelni dotyczące organizacji wydarzeń naukowych z udziałem gości zewnętrznych i studentów, zmusiły organizatorów do przeprowadzenia seminarium JMM z wykorzystaniem środków komunikacji na odległość (aplikacja MS Teams). Pomimo tego, w seminarium JMM wzięło udział ponad 130 osób, w tym przedstawiciele 
Naczelnego Sądu Administracyjnego, administracji wojewódzkich sądów administracyjnych, prawników praktyków, przedstawiciele Ministerstwa Sprawiedliwości oraz administracji organów i instytucji unijnych (Rzecznik Generalny TSUE, Służba Prawna przy Radzie Unii Europejskiej i Radzie Europejskiej). Jak już wcześniej wspomniano, podczas spotkania on-line nie zabrakło dyskusji, polemik oraz pytań badawczych, dających impuls do dalszych badań, w tym również przez członków zespołu grantowego w ramach projektu „Protection of Fundamental Rights in UE”. Owoce seminarium JMM oraz badań naukowych zostaną opublikowane w 7 (2021) numerze czasopisma naukowego Instytutu Prawa i Ekonomii „Rocznik Administracji Publicznej”.

Na zakończenie należy podkreślić, iż na rangę i prestiż wydarzenia miał wpływ nie tylko udział znamienitych prelegentów oraz gości, ale również fakt, iż seminarium JMM patronatu honorowego udzielili: Rektor Uniwersytetu Pedagogicznego im. Komisji Edukacji Narodowej w Krakowie, Rzecznik Praw Obywatelskich, Adwokatura Polska, Naczelny Sąd Administracyjny, Wydawnictwo C.H. Beck, System Informacji Prawnej Legalis Administracja, Fundacja Frank Bold. Wsparcie wydarzenia ze strony tych instytucji bezsprzecznie podkreśliło wyjątkowy charakter przedsięwzięcia, jakim było seminarium naukowe pt. „Pytania prejudycjalne jako środek ochrony praw podstawowych". 